\title{
Environmental risk management on the enterprise to realize green development
}

\author{
Ch. Shanyi ${ }^{1}$ \\ A. Murzin ${ }^{1,2}$ \\ ${ }^{1}$ Southern Federal University (Rostov-on-Don, Russia)
}

Abstract

The environmental risk of an enterprise refers to the impact on the environment and possibility of accidents. In recent decades, the emerging industrial economies represented by BRICS countries have developed rapidly, which has inevitably led to increased pollution and deterioration of environmental quality in these countries. This chapter describes China, which has the fastest economic development among BRICS countries, as an example, and summarizes some evaluation and performance indicators of corporate environmental risk management, so as to facilitate the construction of a scientific and reasonable evaluation indicator system in our further research. The concluding paragraph briefly introduces several measures to reduce the environmental risks of industrial enterprises.

Keywords: environmental risk, environmental risk management, environmental risk assessment, sustainable development of enterprises

\section{For citation:}

Shanyi Ch., Murzin A. (2021). Environmental risk management on the enterprise to realize green development. Strategic Decisions and Risk Management, 12(2), 178-183. DOI: $10.17747 / 2618-947 X-2021-2-178-183$.

\section{Управление экологическими рисками предприятий в целях реализации стратегии зеленого развития}

\author{
Ч. Шаньи ${ }^{1}$ \\ А. Мурзин ${ }^{1,2}$ \\ ${ }^{1}$ Южный федеральный университет (Ростов-на-Дону, Россия) \\ 2 Донской государственный технический университет (Ростов-на-Дону, Россия)
}

\begin{abstract}
Аннотация
Экологический риск предприятия включает аспекты воздействия и возможный ущерб окружающей среде. Последние десятилетия индустриально развитые страны, к которым относятся страны БРИКС, продолжали стремительный промышленный рост, что неизбежно привело к увеличению загрязнения и снижению качества окружающей среды. В настоящей статье в качестве примера рассматривается Китай, экономическое развитие которого характеризуется наибольшими темпами среди стран БРИКС. Также обобщаются некоторые оценочные индикаторы и критерии эффективности корпоративного управления экологическими рисками. Это позволит представить научное обоснование системы оценочных индикаторов. В заключение кратко описаны некоторые меры по снижению экологических рисков промышленных предприятий.
\end{abstract}

Ключевые слова: экологический риск, управление экологическими рисками, оценка экологических рисков, устойчивое развитие предприятий.

\section{Аля цитирования:}

Шаньи Ч., Мурзин А. (2021). Управление экологическими рисками предприятий в целях реализации стратегии зеленого развития. Стратегические решения и риск-менеджмент, 12(2): 178-183. DOI: 10.17747/2618-947X-2021-2-178-183.

\section{Introduction}

The green development of an enterprise is of great significance for sustainable development, and the environmental risk of an enterprise is the key problem of green development. The environmental risk of an enterprise refers to the impact on the environment and possibility of accidents. Among the potential threats for the environment are emissions, wastes, and resource depletion generated during the production process. In recent decades, the rapid development of newly industrialized countries represented by BRICS countries has inevitably led to increased pollution and deterioration of environmental quality in related countries. There are more and more studies of the environmental risks on enterprises, especially industrial enterprises. In 2014, the GDP of BRICS countries accounted for $21.85 \%$ of the total global GDP, while carbon dioxide emissions accounted for $42.21 \%$ of the total global emissions. Global carbon project statistics shows that in 2016, Russia ranked fourth, Brazil and South Africa took twelfth and thirteenth place respectively [Xinjing, Baohua, 2018; National environmental protection.., 2019].

China's carbon emissions rank first in the world while India ranks third, indicating that there is still a lot of room for industrial 
Table 1

Carbon emission efficiency of BRICS countries from 2010 to 2016

Таблица 1

Эффективность выбросов углерода в странах БРИКС, 2010-2016 годы

\begin{tabular}{|c|c|c|c|c|c|c|c|c|}
\hline \multirow{2}{*}{ Country } & \multicolumn{7}{|c|}{ Year } & \multirow{2}{*}{$\begin{array}{c}\text { 7-year } \\
\text { average } \\
\text { growth } \%\end{array}$} \\
\hline & 2010 & 2011 & 2012 & 2013 & 2014 & 2015 & 2016 & \\
\hline Brazil & 6.67 & 6.67 & 6.25 & 6.25 & 5.88 & 5.56 & 5.88 & -11.77 \\
\hline Russia & 1.75 & 1.79 & 1.82 & 1.92 & 1.92 & 1.89 & 1.92 & 9.62 \\
\hline India & 3.13 & 3.13 & 2.94 & 3.13 & 3.13 & 3.23 & 3.23 & 3.23 \\
\hline China & 1.41 & 1.39 & 1.45 & 1.54 & 1.64 & 1.79 & 1.89 & 33.96 \\
\hline South Africa & 1.27 & 1.52 & 1.35 & 1.39 & 1.35 & 1.45 & 1.43 & 12.86 \\
\hline
\end{tabular}

Source: [Xinjing, Baohua, 2018].

environmental improvement. China's total environmental protection investment is continuously increasing, and its share of GDP has gradually stabilized by about $1.4 \%$. During the tenth five-year plan period, the proportion was $1.16 \%$, and during the twelfth five-year plan period, the proportion rose by $1.43 \%$. Judging from the current international experience, environmental protection investment accounted for $1-1.5 \%$ of the country (region)'s total economy that year, indicating that the country (region) was only at the stage of basic control of environmental pollution. China's environmental governance goal is to improve environmental quality, that is, the proportion should reach $2-3 \%$. It can be seen that the scale of China's environmental protection investments still needs further expansion. This article describes China, which has the fastest economic growth and the highest pollution rate among BRICS countries. As an example, it has to introduce the concepts of industrial enterprise environmental risk, enterprise environmental management, and enterprise environmental regulation [Jingshuai, 2020; Yanxia, 2020].

\section{Background}

The concept of environmental risks has been mentioned earlier. Among them are different types of pollution risks: air pollution risk, water pollution risk, solid waste pollution risk, noise pollution risk, radiation pollution risk, and others. Air pollution is the most serious in various energy companies, especially thermal power and steel. Water pollution is the most serious in such industries as paper manufacturing, metal smelting, and chemicals. Several other major aspects of pollution are related to various industrial enterprises. Among them, thermal power, iron and steel, paper manufacturing, metal smelting, and chemical industries have several pollution characteristics at the same time and cause greater serious damage to the environment and the highest environmental risk.

Scholars have also conducted a research taking into account the idea of "environmental risk management $\rightarrow$ changes in enterprise production factors $\rightarrow$ enterprise competitiveness". They believe that environmental risk management has an impact on industrial economy and enterprise production not only at the macro, but also at the micro level.

1. Total factor productivity. Wang Bing and co-authors [Bing et al., 2008] used the "direction distance function" to analyze the relationship between environmental risk management and total factor productivity in many APEC countries and regions. $\mathrm{He}$ found out that the total factor productivity of industrial enterprises is higher in APEC countries and regions that implement environmental risk management, and environmental risk management has a positive and significant impact on actual output. Chen Kunming and co-authors [Kunming et al., 2013] analyzed the impact of different environmental risk management policies on the production efficiency of industrial enterprises through stochastic frontier analysis, and found that environmental risk management policies have a positive and significant impact on the productivity of industrial enterprises and there are obvious differences between these industries. Zhang Huiling and Sheng Dan [Huiling, Dan, 2019] conducted a research on production efficiency of industrial enterprises through frontend environmental pollution control and found out that frontend pollution control can effectively improve the production efficiency of Chinese industrial enterprises and is more suitable for small and private enterprises.

2. Production costs. Bing and co-authors [Bing et al., 2010] and Ye Xiangsong and Peng Liangyan [Xiangsong, Liangyan, 2011] used the environmental loss index method to measure the environmental risk management costs of various regions in China, and found out that most provinces in China have environmental risk management costs. They have greatly increased the production pressure of industrial enterprises. Wang Qunwei and Zhou Dequn [Qunwei, Dequn, 2011] used environmental risk management to calculate the costs in 28 regions of China. The study showed that many industries have greater pressure on environmental risk management costs. There are also drawbacks in the corporate economy.

3. Technological progress. Jie Wu [Solution chalk.., 2008] used DEA method to calculate the Malmqusit productivity index, technical efficiency and technological progress index of 31 provinces and municipalities in China from 1998 to 2004, and conducted an empirical research. The results show that an appropriate increase in pollution control investment and an appropriate reduction in industrial $\mathrm{CO} 2$ emissions have a significant effect on the progress of industrial productivity and production technology. Zhao Hong [Hong, 2008] examined the relationships between environmental risk management in various provinces in China and the R\&D investment of industrial enterprises and the number of patents, and found out that 
environmental risk management has a significant delayed effect. The technological progress of Chinese industrial enterprises has a certain stimulating effect vice versa. Li Qiang and Nie Rui [Qiang, Rui, 2009] also conducted an empirical study of the relationships between environmental risk management and technological progress, and found out that environmental risk management has a significant positive effect on the number of utility model patents developed by industrial enterprises. Zhang Cheng and coauthors [Cheng et al., 2011] conducted this analysis based on the industrial data of 30 provinces in China and found out that there is a U-shaped relationship between the intensity of environmental risk management and the technological progress of enterprises in the eastern and central regions, but this relationship has not been formed yet in the Western region.

4. Technological innovation. Huang Dechun and Liu Zhibiao [Dechun, Zhibiao, 2006] introduced technical coefficients into the Robert model, and found out that while environmental risk management increases direct costs for some companies, it also stimulates some innovations, which can partially or completely offset the cost of environmental risk management. Bai Xuejie and Song Ying [Xuejie, Ying, 2009] used a three-stage DEA model to analyze the impact of national environmental risk management on technological innovation in the thermal power industry in 2004. It is considered that the strengthening of environmental risk management can improve the overall efficiency of China's thermal power industry. At the same time, environmental risk management generally promotes technological innovation, but it is not applicable to all regions.

5. Production efficiency. Hu Angang [Angang, 2008] ranked the production efficiency of 28 provinces, municipalities and regions in China from 1999 to 2005 after the in-depth analysis of environmental factors, and found that there is a significant gap between the production Ranking efficiency that considers pollution emission factors and those that do not take it into account. Jing Weimin and Zhang Lu [Weimin, Lu, 2014] using the framework of biased technological progress and the development of China's green economy under environmental risk management, found that the continuous strengthening of environmental risk management will improve the efficiency of enterprise production to a certain extent.

6. Employment. Chen Yuanyuan [Yuanyuan, 2011] using mathematical models and panel data from various industries across the country from 2001 to 2007 proved that with the continuous strengthening of environmental risk management, employment in various industries will be better provided. $\mathrm{Li}$ Mengjie and Du Weijian [Mengjie, Weijian, 2014] compared the scale and substitution effect of environmental risk management on employment, and first proposed that there are a U-shaped relationships between environmental risk management and employment.

The research on corporate environmental risk can be divided into several aspects. The research lines of Chinese scholars mostly follow those of European and American scholars. Some start with environmental risk management, others - with environmental risk assessment. Strategy management is also taken into account. In terms of environmental risk management, Chinese scholars mostly use various industries for their research. China's industrial system is complete, and all major industries can find actual objects for research in China. According to the current pollution data in China, scholars mainly focus on thermal power, energy, chemical and heavy manufacturing. It is necessary to study the management of the enterprise itself, the environmental responsibility of the management of industrial parks, and the environmental management functions of the government. Most studies are based on China's actual national conditions and can propose targeted solutions to practical problems.

This chapter considers several aspects that can partially solve or reduce the environmental risks of industrial enterprises, but the academic circles have not yet come to a conclusion how to eliminate environmental risks. Taking BRICS countries as an example, their attitudes towards environmental risks of industrial enterprises are not the same as well. In case of China there are currently two major schools in the academic community studying corporate environmental management and environmental risk assessment: one studies natural sciences and conducts general research on environmental risk assessment. The questions of technological development and utilization, environmental pollution and prevention technology, clean production technology, etc. are discussed at the engineering and technical level. The second school is interested in social sciences, management (including accounting and auditing), economics, and law. Corporate environmental pollution and protection issues, such as corporate environmental management, economic evaluation of external environmental damage, accounting confirmation and measurement of related environmental matters, environmental auditing, environmental legislation, etc. [Pigou, 1932; Coase, 1960; Man, 2005; Xu, Zhifang, 2012] are the scope of its research.

This article attempts to demonstrate the problem from the aspects of management innovation as well as the perspective of technological innovation in environmental risk management.

\section{Main focus of the environmental risk management}

1. The task is to clarify the evaluation index system of corporate environmental management. On the example of China in many cases, the environmental management of enterprises lacks quantification and visualization. Therefore, companies need to use quantitative evaluation indicators, process scattered and fragmented information from the scientific point of view, and improve environmental risk management. And this quantitative standard should follow the five principles of systematics, importance, comparability, maneuverability, qualitative and quantitative combination in order to select evaluation indicators. At the same time companies should rely on the relevant research results of the corporate green or environmental performance evaluation indicator system. Compliance evaluation index system is recommended to use while taking into account the aspects of corporate system - environmental friendliness, energy consumption, negative evaluation, and environmental cultural construction as the main measurement indicators.

2. Environmental risk management. The traditional costfollowing theory believes that the improvement of environmental risk management will lead to an increase in the production costs of industrial enterprises, thereby giving the trigger to the growth of 
the industrial economy. Thomas Dean and Robert Brown [Dean, Brown, 1995] found out that environmental risk management will increase the production costs of industrial enterprises, while the rise in pollution control costs will lead to a decreasing costs in production. Consequently, the benefits for undustrial enterprises will grow. Pandej Chintrakarn [Chintrakarn, 2008] adopted the SFA empirical model, and found that environmental risk management did not improve the production efficiency of American industrial enterprises, but increased the pollution control costs and led to economic growth. Li Yunan and Li Ting [Yunan, Ting, 2012] agree that the effects of environmental risk management on industrial economic growth in various regions are different, and the gap is obvious. This is mainly limited by the industrial economic environment, industrial economic development status, geographical environmental conditions, and policy implementation in various regions. Therefore, in the context of continuous improvement of environmental risk management, in order to achieve sustained and stable growth of the industrial economy between regions, it is necessary to develop the environmental risk management and industrial economic development models suitable for each region's development.

Enterprise's response function to environmental risk management. Whether an enterprise conducts environmental management policy, the improvement of environmental management is the result of correlated internal and external factors. The environmental management decision of the enterprise can be described by the enterprise's environmental management reaction function. According to the analysis it can be seen that the external factors affecting corporate environmental management can be divided into two categories: government risk management factors and market factors. Management decisions have a key impact. Therefore, the environmental management decision of an enterprise can be described as the following environmental reaction function (ERF):

$\mathrm{ERF}=\mathrm{f}($ External factors, internal factors $)$.
Управление экологическими рисками предприятий в целях реализации стратегии зеленого развития

The specific content of external and internal factors in the environmental response function is presented in table 2:

Different influencing factors in independent variables will have different effects on the company's environmental management decisions: For some companies, environmental risk management is the main factor that affects the company's environmental management decisions, while for other companies, it comes from the pressure of competitors, the environmental management of upstream and downstream enterprises. The environmental pressure of residents in the district are the main factors that affect the environmental management decisions of enterprises. Among the various influencing factors presented in Table 2, the government environmental risk management is the most basic one. Since the environment has the characteristics of public good, it is difficult to imagine that enterprises will consciously carry out environmental management policy without environmental risk management as the basic point. Therefore, the reaction function of enterprise environmental management can also be called the reaction function of enterprise to environmental risk management, and other influencing factors are derived on the basis of environmental risk management.

3. Corporate environmental management strategy. This paper divides the enterprise's environmental management strategy into green supply chain strategy, green production strategy and green marketing strategy.

- Implementation of the green supply chain strategy in order to achieve environmentally friendly stance at all the stages of enterprise activities. In the green management of the supply chain, environmental benefits, resource benefits, and environmental protection effects need to be considered comprehensively. When selecting cooperative enterprises, one can focus on companies with successful environmental management, intention to cooperate, build a strategic alliance for environmental management and control. Establishing a green supply chain strategy cannot

Table 2

Analysis of influencing factors of environmental risk management response function Таблица 2

Анализ факторов влияния в функции реагирования управления экологическими рисками

\begin{tabular}{|c|c|c|c|}
\hline Dependent variable & \multicolumn{3}{|c|}{$\begin{array}{l}\text { Industrial environmental management decision } \\
\text { (necessity to conduct environmental management and the depth of environmental management) }\end{array}$} \\
\hline \multirow{8}{*}{ Independent variable } & Type & Specific influencing factors & Factor analysis \\
\hline & \multirow{4}{*}{$\begin{array}{l}\text { External } \\
\text { factors }\end{array}$} & $\begin{array}{l}\text { Specific impact on } \\
\text { environmental risk } \\
\text { management }\end{array}$ & $\begin{array}{l}\text { Different types of environmental risk management, implementation } \\
\text { status (indirectly dependent on economic development status), } \\
\text { and degree of strictness of environmental risk management }\end{array}$ \\
\hline & & Market environment & $\begin{array}{l}\text { The market structure, the degree of monopoly and competition, } \\
\text { the position of the company in the production chain }\end{array}$ \\
\hline & & Social factors & $\begin{array}{l}\text { Social environmental awareness, environmental pressure from } \\
\text { customers and residents }\end{array}$ \\
\hline & & Competitor behavior & $\begin{array}{l}\text { Relationship with competitors (whether competition } \\
\text { or conspiracy exist) }\end{array}$ \\
\hline & \multirow{3}{*}{$\begin{array}{l}\text { Internal } \\
\text { factors }\end{array}$} & Enterprise technology status & $\begin{array}{l}\text { Enterprise's production function, factor constraints, } \\
\text { pollution control technology }\end{array}$ \\
\hline & & Corporate strategic positioning & $\begin{array}{l}\text { Long-term vision is still necessary for quick success, } \\
\text { based on domestic or international markets }\end{array}$ \\
\hline & & Management factor & Manager's ability, environmental awareness, etc. \\
\hline
\end{tabular}

Source: [Man, 2005]. 
only strengthen employees' awareness of environmental protection, but also promote the development of environmental management of other companies in the supply chain, and form a consensus on the green development of the entire supply chain. With the help of green production technology and taking into account the green development of the entire society, the output of three wastes in the production process can be reduced as well as resource consumption.

- Implementation of green production strategy. In the process of green production, enterprises can use new sources of energy to replace conventional energy, or reduce the use of conventional energy as much as possible, and carry out technological upgrading and transformation, introduce high-tech and advanced equipment, and promote the industrial upgrading and transformation of enterprises. When selecting raw materials for production, non-toxic materials should be chosen, and the amount of raw materials should be precisely controlled to reduce resource consumption. In the production process, of key importance is to simplify it, control the discharge of pollutants during the production process and use new technologies and processes to extend the life cycle of the product, so as to maximize the value of the company's environmental management and control measures.

- Implementation of green marketing strategy. Product marketing is the complete display of products to users in order to realize the benefits of enterprise products. The use of green marketing methods can shape a company's green and environmentally friendly image and reflect the green attributes of the product itself.

\section{Limitations and discussion}

Environmental risk management is a necessary prerequisite for modern enterprises to achieve sustainable development. The goal of scientific environmental risk management is to achieve ecological and green sustainable development of the manufacturing industry, which is in line with the basic trend of current global development. In the actual management link, the staff needs to take into account the local common natural disasters and the data about environmental quality status, sort out environmental problems, estimate possible hazards, and formulate corresponding prevention plans [Dongning, Changhui, 2005].

Since environmental risk management is beneficial to the development of the industrial economy or it restricting the development of the industrial economy, the solution to this problem is the key to the government and various industrial departments formulating and implementing specific environmental risk management measures. To explain the practical effect of environmental risk management on China's industrial economic growth, and to propose what environmental risk management policies must be adhered to in order to achieve a win-win situation for environmental protection and industrial economic growth are of key importance. The implementation of environmental risk management needs to be based on the status quo of regional development to ensure that environmental risk management is as small as possible to inhibit industrial economic growth. The research in this article still lacks empirical approach, which will be further proved by combining relevant models.

\section{References}

1. Angang H. (2008). The provincial technical efficiency ranking considering environmental factors (1999-2005). The Quarterly of Economics, 3: 933-960.

2. Bing W., Yanrui W., Pengfei Y. (2008). Environmental regulation and total factor productivity growth: An empirical study of APEC. Economic Research, 5: 19-32.

3. Bing W., Yanrui W., Pengfei Y. (2010). China's regional environmental efficiency and environmental total factor productivity growth. Economic Research, 5: 95-109.

4. Cheng Z., Qianlong Z., Tongshen Y. (2011). The relationship between environmental pollution and economic growth. Statistical Research, 1: 59-67.

5. Chintrakarn P. (2008). Environmental regulation and U.S. states' technical inefficiency. Economics Letters, $100(3)$ : $363-365$.

6. Coase R.H. (1960). The problem of social cost. The Journal of Law and Economics, 3: 1-44.

7. Dean T.J., Brown R.L. (1995). Pollution regulation as a barrier to new firm entry: Initial evidence and implications for future research. The Academy of Management Journal, 1: 288-303.

8. Dechun H., Zhibiao L. (2006). Environmental regulation and enterprise independent innovation: The construction of enterprise competitive advantage based on Porter's hypothesis. China Industrial Economy, 3: 100-106.

9. Dongning Y., Changhui Z. (2005). The driving force for enterprises to voluntarily adopt a standardized environmental management system: Theoretical framework and empirical analysis. Management World, 2: 85-95+107.

10. Huiling Z., Dan S. (2019). The impact of front-end pollution control on the productivity of Chinese enterprises-a study based on the boundary breakpoint regression method. Economic Review, 1: 75-90.

11. Hong Z. (2008). The impact of environmental regulation on industrial technological innovation: Empirical analysis based on China's panel data. Industrial Economics Research, 3: 35-40.

12. Jingshuai L. (2020). Ecological and environmental risk identification and environmental risk management. Science and Technology Innovation Herald, 12: 120-121.

13. Kunming C., Yanda J., Guangnan Z. (2013). The impact of environmental protection policies on the production efficiency of "Made in China". Statistical Research, 9: 37-43. 
14. Man Z. (2005). Research on the correlation mechanism between environmental regulation and enterprise behavior. Research on Financial and Economic Issues, 4: 34-39.

15. Mengjie L., Weijian D. (2014). Does the double dividend of environmental regulation and employment apply to China at this stage? Empirical analysis based on inter-provincial panel data. Economic Science, 4: 14-26.

16. National environmental protection standards of the people's Republic of China (2019). URL: http://www.mee.gov.cn/ywgz/fgbz/bz/ bzwb/other/pjjsdz/201810/W020181026519881869834.pdf.

17. Pigou A.C. (1932). The economics of welfare. London, Macmillan.

18. Qiang L., Rui N. (2009). Environmental regulation and regional technology innovation: An empirical analysis based on China's provincial panel data. Journal of China University of Economics and Law, 4: 18-23.

19. Qunwei W., Dequn Z. (2011). Research on carbon dioxide regulation cost based on environmental production technology - taking panel data of 28 provinces in China as an example 11. Scientific Research Management, 2: 114-121.

20. Solution chalk. Environmental regulation and China's industrial productivity growth. Industrial Economic Research, 1: 19-25.

21. Weimin J., Lu Z. (2014). Environmental regulation, opening to the outside world and the progress of green technology in China's industry. Economic Research, 9: 34-47.

22. Xiangsong Y., Liangyan P. (2011). Research on regulatory efficiency and total factor productivity under China's environmental regulation: 1999-2008. Finance and Trade Economics, 2: 102-109.

23. Xinjing W., Baohua Z. (2018). Research on the influencing factors of carbon emission efficiency in BRICS countries. Journal of China Academy of Environmental Management, 6: 55-58.

24. Xu X., Zhifang Z. (2012). Research on enterprise environmental risk management and environmental liability assessment framework. Auditing and Economic Research, 2: 33-40.

25. Xuejie B., Ying S. (2009). Environmental control, technological innovation and the efficiency improvement of China's thermal power industry. China Industrial Economics, 8: 68-77.

26. Yanxia Y. (2020). Construction of risk environment assessment index system. China New Technology and New Products, 11: 105-107.

27. Yuanyuan C. (2011). The impact of industry environmental regulation on employment Empirical research: Empirical analysis based on 25 industrial industries. Contemporary Economic Science, 3: 67-73.

28. Yunan L., Ting L. (2012). The dynamic relationship between environmental regulations, factor endowments and export trade: Based on dynamic panel data of my country's pollution-intensive industries. International Economics and Trade Research, 1: 34-42.

\section{About the authors}

\section{Cheng Shanyi}

Graduate student, Southern Federal University (Rostov-on-Don, Russia).

Research interests: environmental management, sustainable development, green manufacturing, green regional economy, government environmental regulation.

8632015@qq.com

\section{Anton Murzin}

Associate professor, Southern Federal University, Don State Technical University (Rostov-on-Don, Russia). ORCID 0000-0001-91908919, Researcher ID F-6037-2014, SPIN 5019-8260, AuthorID 389884.

Research interests: risk management, sustainable development, territorial development, modeling, management. admurzin@sfedu.ru

\section{Информация об авторах}

\section{Чен Шаньи}

Аспирант, Южный федеральный университет (Ростов-на-Дону, Россия).

Область научных интересов: экологический менеджмент, устойчивое развитие, экологичное производство, экологичная региональная экономика, государственное экологическое регулирование.

8632015@qq.com

\section{Антон Мурзин}

Доцент, Южный федеральный университет, Донской государственный технический университет (Ростов-на-Дону, Россия). ORCID 0000-0001-9190-8919, Researcher ID F-6037-2014, SPIN 5019-8260, AuthorID 389884.

Область научных интересов: риск-менеджмент, устойчивое развитие, развитие территорий, моделирование, управление. admurzin@sfedu.ru

Статья поступила в редакцию 5.04.2021; после рецензирования 19.04.2021 принята к публикации 27.06.2021. Авторы прочитали и одобрили окончательный вариант рукописи.

The article was submitted on 5.04.2021; revised on 19.04.2021 and accepted for publication on 27.06.2021. The authors read and approved the final version of the manuscript. 